\title{
GCU
}

Glasgow Caledonian

University

University for the Common Good

\section{The North Coast 500: developing tourism in the northern Scottish Highlands}

Lennon, J. John; Harris, John

Published in:

Scottish Affairs

DOI:

10.3366/scot.2020.0317

Publication date:

2020

Document Version

Author accepted manuscript

Link to publication in ResearchOnline

Citation for published version (Harvard):

Lennon, JJ \& Harris, J 2020, 'The North Coast 500: developing tourism in the northern Scottish Highlands', Scottish Affairs, vol. 29, no. 2, pp. 223-253. https://doi.org/10.3366/scot.2020.0317

\section{General rights}

Copyright and moral rights for the publications made accessible in the public portal are retained by the authors and/or other copyright owners and it is a condition of accessing publications that users recognise and abide by the legal requirements associated with these rights.

Take down policy

If you believe that this document breaches copyright please view our takedown policy at https://edshare.gcu.ac.uk/id/eprint/5179 for details of how to contact us. 


\title{
J John Lennon and John Harris
}

\section{The North Coast 500: Developing tourism in the Northern Scottish Highlands}

\begin{abstract}
This paper looks at the development of the North Coast 500 (NC500) route as a key initiative contributing to the increase of tourism in one of the least visited parts of Scotland. Drawing upon data on visitor numbers within the area between 2014-2018 it considers whether the NC500 has catalysed and encouraged tourism to an area of the country that has for many years been a peripheral region in terms of visitation. The findings highlight that the route seems to have had an impact upon a number of different aspects of tourism within the area generating increased expenditure and employment.
\end{abstract}

Keywords: Route tourism, peripheral region, economy, impact

Professor John Lennon is Dean of the Glasgow School for Business and Society and Director of the Moffat Centre for Travel and Tourism Business Development at Glasgow Caledonian University. In the commercial sector of travel and tourism John has undertaken over 700 tourism and travel projects in over 50 nations on behalf of private sector and public sector clients. Professor John Harris is Associate Dean Research in the Glasgow School for Business and Society at Glasgow Caledonian University. Ongoing research includes work on the cultural politics of sporting celebrity, and the (re)presentation of national identities in tourism.

Declaration Professor J John Lennon is a Non-Executive Director of North Coast 500 Limited 


\section{Introduction}

The North Coast 500 (NC500) is a 516-mile-long route across some of the most scenic parts of Scotland. Launched in 2015, it is described as 'the new scenic route showcasing fairy-tale castles, white sand beaches and historical ruins' (NC500, 2018). The key aim of the NC500 was to create a northern coastal route that traverses the meeting of land and sea and operated as a coherent tourist route. The route links spectacular natural heritage and scenery with a range of quality visitor provision to connect activities, attractions, food, beverage, accommodation and retail. The defining characteristic of these products and services is their quality, regional connectivity and links to the culture and context of the Northern Highlands. The focus framing the development of this route was to create a coherence in supply and service offerings that reaffirm and support the quality of the natural environment.

An article on the BBC website in 2018 highlighted how Scotland was outperforming the UK in tourism for the sixth year in a row. This also noted the importance of the NC500:

A decade ago it was a relatively well-kept secret - a circular route, often on single-track roads, through breathtaking scenery in the far north of Scotland. But no more. Now known as the North Coast 500, it has been cleverly marketed as one of the world's great road trips. (BBC, 2018a)

The northern landscape in Scotland has been described as one of the most breathtaking in Europe providing contrast and drama in a route that could become an aspiration and an iconic representation for the northern Highland visitor. It was listed by Lonely Planet as one of the top regions in the world to visit in 2019 (BBC, 2018b). This part of Scotland (along with the Islands) is amongst the least visited areas in the nation (see VisitScotland, 2019). The cost and time involved in getting to this part of the country and the relatively lower density of developed 
visitor attractions has served to limit both international and domestic visitation. Similarly, levels of day visitation remain low given the distance from major population centres both within Scotland and other parts of the United Kingdom. Such an area may be regarded as a peripheral region in both the Scottish and broader UK tourism sectors. Peripheral places face significant challenges in relation to the development of tourism and are often characterised by limited levels of investment and infrastructure development. Basu (2007, p.17) notes how the Highlands have "repeatedly been constructed as the primitive/peripheral/exotic "other" to the hegemonically dominant Scottish Lowlands, England and/or the Anglophone British state'. Prior to consideration of the emerging literature around the topics of route tourism and drive tourism, we begin by providing a brief overview of the important role of tourism in Scotland.

\section{Tourism in Scotland}

Scotland has long been an established destination for tourism and a country that is widely recognised as a strong brand in international tourism (see McCrone, Morris \& Kieley, 1995; Pritchard \& Morgan, 1996). In his history of the Scottish nation, Devine (2000) notes the transformation of the perception of the Highlands in the late 1700s 'from a barren wilderness to a place of compelling natural beauty' (p.243). The improvements in transport links meant that tourism reached further into the Highlands over the next century, and as much of Britain underwent a period of rapid urbanisation and industrialisation, the romanticization of the Highlands meant that the area assumed a special place in representations of the nation (Devine, 2000).

Scotland is often referred to today as a well-developed tourism destination. Much of this focuses on Edinburgh, which is enduringly popular with overseas visitors to the United Kingdom (UK) and is usually listed as second only to London in lists detailing the most popular 
places to visit (VisitBritain, 2019a). In more recent years Scotland's largest city, Glasgow, has also emerged as a key location for tourism development. Since being selected as the European City of Culture in 1990, the city has hosted major events such as the 2014 Commonwealth Games and 2018 European Championships.

Although tourism in Scotland is dominated by the city products of Edinburgh and Glasgow, the nation also offers a combination of rural, coastal, highlands and islands products. Whilst seasonality remains a concern in much of the country, with greatest demand for accommodation and attractions between May and October, the urban products of Edinburgh and Glasgow show lower levels of seasonality and enjoy greater volumes of visitation throughout the year (VisitScotland, 2019). This reflects a lower dependency on leisure-based tourism than the rural, coastal and island regions. These two main urban centres (Edinburgh and Glasgow) are the locations of $65 \%$ of the most popular visitor attractions and offer the most diverse mix of demand from leisure, business, meeting and conference visitors (VisitScotland, 2019).

Outside of these main city offerings in the central belt of Scotland, we can look at some other parts of the country as being peripheral to core tourism markets. There are many challenges involved in developing tourism in peripheral areas (Nash \& Martin, 2003). As noted previously, this particular part of Scotland can be perceived as a marginal area in a number of different ways (see Basu, 2007). Developing a destination brand represents a more complex task than developing a brand identity for many other products and services (Pike, 2005). Before looking at the specific case of the NC500 the next sections briefly outline the developing body of research in the areas of route tourism and drive tourism. 


\section{Route tourism}

Route tourism is a developed element of the product mix and is sometimes conflated with themed routes, trails, and scenic routes (Timothy \& Boyd, 2015). Such developments have been particularly useful in increasing visitor numbers to less explored areas. Wine routes have been successful in a range of destinations and have been widely studied. Mitchell, Charters and Albrecht (2012) highlighted how wine tourism can be situated within and around the broader rural mythology and the regional wine cultural complex to develop tourism. Thanh and Kirova (2018) used the experience economy model to explore the wine tourism experience. In a Scottish context, whisky has been successfully tagged to the Highlands for a number of years, with various businesses capitalising on the strong association between Scotland's national drink and tourism (see Martin \& McBoyle, 2006; Stoffelen \& Vanneste, 2016). Stoffelen and Vanneste (2016) highlight the importance of whisky as a symbol of Scottish cultural identity and note how whisky tourism offers important benefits to the Scottish economy. The Scotch Whisky Association (2019) suggested that the industry contributes over $£ 5.5$ billion to the UK economy in 2018 .

Routes and trails have been a part of our civilisation for centuries. They cross nations and boundaries connecting cities and destinations across the globe and have historical origins in trade, migration and military use (Dolesh, 2004; Kent, 1993; Timothy \& Boyd, 2015). Their role in tourism has been mixed and early records of pilgrimage trails cross into our understanding of early tourism behaviour. More recently trails have become omnipresent across the globe in destinations throughout the world. Their success is variable, and scholars have struggled to identify the fundamental elements that lead to appeal and enduring levels of visitation (Timothy \& Boyd, 2015).

\section{Drive tourism}


Another term that has been used to describe this phenomenon is drive tourism. For many years the car was a topic ignored by those writing about culture and societies (Miller, 2001). More recently, we have seen an increased interest in self-drive tourism (see Prideaux \& Carson, 2011). Car based transport has long been a popular form of exploration of Scotland (VisitBritain, 2019b). Indeed, there is now a developing body of research focusing on drive tourism that highlights the importance of this particular area to broader economic development (e.g. Hardy, 2003; Prideaux \& Carson, 2011; Rolfe \& Flint, 2018). Drive tourism incorporates family car, rental, four-wheel drive, caravanning, travel and recreation vehicles, motorhomes and motorcycles (Prideaux \& Carson, 2011). Cars remain the most significant form of transport for tourists in economies such as the US and the UK (Timothy, 2011) hence the inherent logic of drive-based tourism in the development of the NC500. As Carson and Carton (2011, p.297) noted 'regional destinations in developed countries in Australia, the Americas and Europe could expect to have three-quarters of their visitors arrive by private or hired vehicles.' Furthermore, such drive tourists are independent and can be flexible in their choice of destinations hence the challenges of marketing routes remain.

When we look at the topic of drive tourism then we often see a focus on themed routes. Hardy (2003: p.314) outlines some of the key factors relevant here:

Themed touring routes have been advocated as opportunities to link regional communities together, form partnerships, encourage tourism development along commonly travelled routes, provide a more satisfactory tourism experience and maximise economic benefits to local business people by encouraging longer stays and greater spending in the region. 
Sykes and Kelly (2016) have also noted the benefits of attracting motorcyclists to rural areas. Creating themed touring routes has been identified as one of the best ways for rural regions to work together. A joined-up and coordinated approach is particularly important here since it allows stakeholders to work together and helps to develop an integrated and coherent offering that can help differentiate a particular route from other brands and destinations.

Many routes have been developed in different parts of the world. The success, and now somewhat iconic status, of Route 66 in the United States of America is often referred to when there is any discussion of drive tourism (see Caton \& Santos, 2007). Route 66 was one of the original highways in the US highway system that became popularised in music and television. The development of new roads impacted upon its importance and many towns across the route became 'ghost towns' but after a period of decline a growing interest in nostalgia tourism has allowed many towns brand themselves with the Route 66 trademark. Hardy (2003: p.317) noted that:

One of the advantages of route-based tourism is that while travellers may opt in and out of the route, they are able to diffuse demand along both the route itself and its surrounding localities.

The concept of themed routes as tourist attractions has gained prominence in recent decades (Timothy \& Boyd, 2015). Such routes act to link a range of attractions together that independently would have more limited appeal. The synergy of linked route elements is aimed at growing the number of 'pull' factors and dispersing visitor expenditure among a larger number of recipients. Rolfe and Flint (2018: p.169) note that 'despite the increasing importance of drive tourism there have been very few published studies on this market'. To further develop our understanding of this topic this paper uses the case of the NC500 to explore the impact that 
such a development can have on tourism in a particular area. The NC500 is a circular route of 516 miles that was launched in May 2015 in the Highlands and Islands region of Scotland one of the most remote wilderness locations in Europe (see Figure 1).

\section{$<<$ INSERT FIGURE 1 ABOUT HERE $>>$}

It connects member businesses in all aspect of the tourism offer including accommodation, hospitality, visitor attractions, retail and activities. The next section outlines the methodology used in this study.

\section{Methodology}

The evaluation of the economic and employment impacts of the NC500 was commissioned in spring 2019 by the North Highland Initiative, an economic development agency for the Northern Highlands of Scotland which receives funds from the Prince of Wales Trust and Highlands and Islands Enterprise. The Moffat Centre were successful in tendering for the project and undertook the analysis from June to September 2019 and results were reported the following month (Moffat Centre, 2019).

It is estimated that there are 1,900 tourism related businesses on or near the route of the NC500 (this is calculated based on a corridor around the route of circa 10 miles either side where landscape allows). Of these some $380(20 \%)$ were contacted. This sample was representative of the range of tourism (and other) businesses on the route and included accommodation, activities, attractions, vehicle hire and retail (where a significant proportion of purchases could be accredited to visitor markets). Some 300 businesses responded giving a response rate of $78.9 \%$ with useable data for the period of examination (baseline 2014 to 2018). The sample 
providing data constituted $20 \%$ of the estimated 1,900 businesses on the route. However, responses were self-selecting rather than the result of random selection yet the mix of business type in the response ensured representativeness by sector as detailed below.

Data was collected through the Moffat Centre, whose work on the collation of visitor attraction national statistics for Scotland, England, Wales and Northern Ireland has spanned almost two decades. This gives an unprecedented understanding of visitor flows, expenditure, product development and performance of the sector particularly in Scotland (Moffat Centre, 2018). The Moffat Centre also undertakes the Scottish Occupancy and Accommodation survey that looks at all forms of accommodation expenditure which enables researchers to overlay accommodation performance on visitor surveys, attraction performance and output (Moffat Centre, 2019). These data sources provided foundation information on which to build the NC500 survey that forms the focus of this paper.

\subsection{The Economic Impact of the NC500 and the use of Multipliers}

The main concept of the multiplier is based on the recognition that the various sectors that make up the economy are interdependent. This means that in addition to purchasing primary inputs, such as labour and imports, each sector will also purchase intermediate goods and services produced by other companies within the local economy, in this case Scotland. Manipulation of the Input-Output tables allows estimation of different types of multipliers depending on whether there is an interest in output, employment or income effects.

The Scottish Government provides guidance on the relevant output, employment and income multipliers for differing standard industrial classifications (Scottish Government, 2019). The main building block for calculating multipliers is the Leontief Inverse matrix. This is derived 
from the symmetric industry-by-industry use matrix and shows how much of each industry's output is required, in terms of direct and indirect requirements, to produce one unit of a given industry's output.

\section{Output multipliers}

\section{Type I}

The Type I output multiplier for an industry is expressed as the ratio of direct and indirect output changes to the direct output change due to a unit increase in final demand. Multipliers therefore represent marginal changes and cannot strictly be applied to large changes. The multiplier is derived by summing the entries in the relevant column of the Leontief Inverse matrix.

Type II

It is also possible to calculate a Type II output multiplier. The Type II output multipliers are expressed as the ratio of direct, indirect and induced output changes to the direct output change due to a unit increase in final demand. These multipliers take into account increased consumption and therefore output which will be generated from higher personal incomes. Consumers' spending is included in the calculation of the Type II multipliers by expanding the industry by industry matrix to include the income from employment row and the consumer's expenditure column.

\section{Employment multipliers}

The employment multipliers tend to be the most commonly used of the multipliers made available through extensions to the input-output tables. This is due to their use in economic impact analysis which is often preoccupied with the employment effects of either industrial expansion or company closure. The employment multiplier which is analogous to the Type I 
output multiplier is the ratio of direct plus indirect employment change to the direct employment change. Similarly, there is a Type II multiplier which measures the ratio of direct, indirect and induced employment change to the direct employment change (Scottish Enterprise, 2012).

\section{Income multipliers}

It is also possible to calculate both Type I and Type II income multipliers. These measure the change in income (wages, salaries, profits) which occur throughout the economy as a result of a change in Final Demand. This type of analysis differs from economic impact analysis in that it is concerned with predicting the effect of across-the-board changes in Final Demand rather than individual sector changes (Scottish Government, 2019). This type of Scottish forecasting could be used, for example, to analyse an increase in consumer expenditure or an increase in exports.

It is interesting to note that the industry which would experience the largest output effect is not necessarily the industry where the largest number of jobs increase will occur. Estimates of job increases are dependent on employment to output ratios for that particular industry, hence the more labour-intensive industries such as leisure and tourism will see a larger proportionate increase in employment than other sectors.

The nature of the data sought (e.g. sales performance, occupancy and rates achieved), were for many businesses seen as commercially valuable and sensitive. In addition, many of these businesses are classed as micro-businesses and are frequently characterised by very limited record keeping. Accordingly, understanding of medium-term impacts across the period 20142018 was challenged by timing, commercial confidentiality and data availability. Whilst the 
NC500 officially commences in Inverness, data for the Highland capital has been deliberately omitted, since it would distort overall performance indicators. Isolating NC500 impacts from the general urban tourism performance of Inverness would be complicated and methodologically difficult to both calculate and justify. Indeed, there is no detailed city tourism data available for Inverness in terms of city visitation thus compounding the methodological challenge. A further complication arises from the macro-environment and the extent to which the ongoing uncertainty around the United Kingdom's decision to leave the European Union influenced international (and particularly European tourist visitation). This is further reinforced by other Brexit impacts including the movement in currency exchange rates between UK Sterling and other major currencies (such as the Euro and US\$) creating a strong value offer that may contribute to or catalyse visitation in whole or in part.

\section{Results}

In total, 380 businesses were contacted and responded to the survey. Of these some 203 were accommodation related. This is the most significant and dispersed sector and is an important indicator of increased demand and visitation. The accommodation response rate is detailed in Table 1.

$<<$ INSERT TABLE 1 ABOUT HERE $>>$

The visitor attraction, activity and retail sectors constituted the remaining 177 businesses and the most significant category responses were from visitor attractions. This data has been supplemented by Moffat Centre data on visitation to visitor attractions which has been 
continuously collected since 2000 (Moffat Centre, 2018). Accordingly, a useable aggregate sample of $72.1 \%$ was available with high quality continuous sample data of $41.2 \%$.

Table 2 outlines the sources of data utilised to inform the performance analysis of the relevant sections of the Scottish Visitor attraction sector.

$<<$ INSERT TABLE 2 ABOUT HERE $>>$

The other tourism related businesses constituted a mix of activity provision including tour operators, retail offers, and hospitality. This mixed sector constituted a significant proportion of micro-enterprises. Table 3 outlines the number of organisations contacted and the response rate for the mixed sector.

$<<$ INSERT TABLE 3 ABOUT HERE $>>$

\section{NC500: Accommodation Performance}

The aggregate accommodation performance (room occupancy) across the period 2014-2018 shows clear growth from $52 \%$ in 2014 , prior to development of the NC500, to $82 \%$ in 2018 (see Table 4). This is a year-round occupancy indicator suggesting seasonal extension and is verified by other indicators such as road usage and attraction visitation which will be considered later in this paper. 
The aggregate accommodation rate achieved (revenue per available room) across the period 2014-2018 shows clear growth from $£ 46$ in 2014 to $£ 82$ in 2018. Clearly, any increase has to be viewed in the context of the overall movement in tourism across this period and a weighting for the generic national increase in accommodation occupancy and rates has been factored into the calculation of the impact of the NC500. The other complexity with accommodation relates to the significant increase in supply through the availability of private accommodation stock via organisations such Airbnb and other online consolidators. The data for Airbnb is notoriously hard to obtain, with significant charges involved for data supply. However, this increase in supply deflates traditional indicators giving the impression of lower than actual demand.

The quality of accommodation has also increased significantly according to VisitScotland's quality assurance scheme. However, this scheme has lost considerable support and buy in and the NC500 business quality also had to be evaluated against the much more representative Trip Advisor ratings. The review shows a growth in quality which suggests investment in assets. This is reinforced by data provided by banks and lending agencies that suggests an increase in investment in hospitality and accommodation provision over the period 2014-2018. The data on individual cases remains confidential and aggregate calculations across the sector are difficult because of the range of lending agencies and access to detailed data. However, the tangible and observable trend in quality improvement is to some extent reflected in the positive movement in rates achieved as outlined in Table 5.

$<<$ INSERT TABLE 5 AROUND HERE $>>$ 


\section{NC500: Visitor Attraction Performance}

The performance of relevant visitor attractions in this region is also positive and it has been possible to incorporate Moffat Centre data from 2014-2018 across a constant sample of attractions. Over this period the performance of paid attractions is stronger than free admission bringing greater economic impact (see Table 6).

$<<$ INSERT TABLE 6 AROUND HERE $>>$

This cumulative analysis includes a number of attractions that wish to maintain confidentiality of performance but allow data to be used in aggregate calculations. The pattern is overwhelmingly positive with only $14 \%$ of attractions experiencing a reduction in visitation over the period whilst $86 \%$ experienced growth (see Table 7). Clearly, any increase has to be viewed in the context of the overall movement in tourism across this period and a weighting for the generic national increase in visitor attraction performance has been factored into any calculation of the impact of the NC500.

$<<$ INSERT TABLE 7 AROUND HERE $>>$

\section{NC500: Other Tourism Related Businesses Performance}

The other tourism related businesses constituted a mix of activity provision including tour operators, retail offers, hospitality, car hire, and petrol stations. These operators varied from those catering solely for visitors to the area to those for whom tourists were a part of the wider demand. This creates significant difficulties in separating visitor demand from resident/local demand. This mixed sector also constituted a significant proportion of micro-enterprises where record-keeping and consumer understanding was limited. However, a response rate of $19.4 \%$ was achieved and in these cases data was usable (see Table 8). 
$<<$ INSERT TABLE 8 AROUND HERE $>>$

Despite the limited sample, many of those surveyed indicated that there was an identifiable increase in visitors and sales across the period. Invariably, it is difficult to attribute such data to the NC500, however it is the consistent response across the duration of the period 2014-18 and the growth since 2014 that is revealing. This is important since the mere presence of large numbers of self-drive tourists does not necessarily or automatically provide economic benefits (Greiner et al., 2004).

\section{NC500: Other Tourism Related Indicators}

There are other important indicators of growth in business provided from a variety of sources but which are less quantifiable and difficult to utilise in developing economic impacts. For example, data from the association of independent camper van hire records that in 2014 only two or three operators were renting vehicles for the NC500 route. That figure has now increased to around 40 such providers in 2018. Similarly, the major banks and building societies contacted as part of this project have indicated that since 2014 requests for business loans related to NC500 business operations have increased by a factor of 6 over the period to 2018 . The available traffic counters for the route have also been examined across the period of 20142018 for key route elements (see Figures 2-8). The cumulative counts for the Highlands of Scotland show clear evidence of growth with 2015 onwards being particularly busy. 
$<<$ INSERT FIGURE 2 AROUND HERE $>>$

$<<$ INSERT FIGURE 3 AROUND HERE $>>$

The above graph highlights and concentrates on all Highland traffic over a shorter period 20102018. Looking specifically at the A9 growth in utilisation is clearly evident particularly since 2012-2013 (see Figures 4 and 5).

$<<$ INSERT FIGURE 4 AROUND HERE $>>$

$<<$ INSERT FIGURE 5 AROUND HERE $>>$

Figure 5 concentrates on the period since 2010 and the growth from 2015 is apparent. However, the A9 is a major arterial route to and from the Highlands of Scotland. The specific traffic counter data on the route available from Transport Scotland indicates clear increases in motor vehicles on the A836, A837 and A832 (see Figures 6, 7 and 8). This confirms the increase in visitation and reinforces other indicators such as visitor attraction visitation and accommodation occupancy. 
$<<$ INSERT FIGURE 7 AROUND HERE $>>$

$<<$ INSERT FIGURE 8 AROUND HERE $>>$

\section{Understanding the economic impact of the NC500}

The economic impact of the NC500 has been analysed for the most recent year of operation where data is available. The key data sources utilised included; the Scottish Occupancy and Accommodation Survey (Moffat Centre, 2019) and the Scottish Visitor Attractions Monitor (Moffat Centre, 2018). The fundamental variables here are the extent to which the NC500 has increased visitation (number of visitors) and increased expenditure (in all categories). These are tangible and quantifiable elements that can then be used to calculate sales through a number of outlets and channels on and around the route. These have to be mapped and the extent to which they are visitor facing (e.g. retail) has to be considered. The relative density of offers will also impact on possible spending (e.g. number of commercial businesses) and the fact that if demand increases the number of businesses is likely to increase.

\section{Developing the economic value of the NC500}

The fundamental calculation is thus based on increased visitation plus expenditure calculated for 2018. This is linked to an understanding of dwell time and related income multipliers that are used to calculate direct, indirect and induced impacts. Input output tables and economic multipliers (direct, indirect and induced) are used to detail the relationship between producers and consumers and the interdependence of tourism and other industries (Scottish Government, 2019). At a global level the United Nations World Tourism Organisation (UNWTO) considers the value of the sector at a regional and national level according to economic criteria such Gross 
Domestic Product and Gross Value Added (UNWTO, 2019). Similarly, employment impacts are considered in direct, indirect and induced measures and a proportion of total national employment

A concern in any such calculation is holding constant all other factors which may impact on visitation. For example, Dunrobin Castle is an established and successful visitor attraction and is likely to continue with its own attraction marketing making sole attribution of NC500 impacts difficult. In other parts of the NC500, wherein awareness and marketing has been less of a focus, attribution will be easier. Other variables that have to be held constant include currency and consumer prices index both are likely to continue to be impacted by macroeconomic effects.

Employment is calculated as a development function of existing employment as well as a function of sales which can be calculated as a ratio of increased sales in different channels (e.g. accommodation, food, beverage, attractions). Other related elements include rates of business growth and displacement impacts (i.e. reducing the calculation by a factor that accounts for those who would have visited the Highlands anyway). In addition, the Moffat Centre data utilises values at basic prices (net of VAT) since this is essentially a central tax and should not be accounted for at a local level as expenditure. Accordingly, the following economic and employment impacts were derived assuming no major economic or environmental 'shocks' over the period of growth.

\section{Calculating NC500 Route Impacts}

The initial calculation was based on the median performance of businesses on and around the route (calculated at circa 1,900 in total). This is inevitably an estimation that will be valid for 
a relatively short time frame and includes many businesses which are only partially catering to tourist markets. Some 380 businesses were contacted for this research with a series of valid response levels across the different sectors. This means the calculation of visitors and job creation has to consider what proportion of annual impact is as a result of the NC500.

The high-level indicators for cumulative impacts are detailed in Table 9.

$<<$ INSERT TABLE 9 AROUND HERE $>>$

The calculation for Total Output GVA for the businesses that comprise the NC500 is detailed in Table 10.

$<<$ INSERT TABLE 10 AROUND HERE $>>$

The calculation of employment is detailed in Table 11 and does not include Inverness. It estimates a proportion of FTE for those businesses such as retail and car hire who have additional consumer servicing beyond visitors to the NC500.

$<<$ INSERT TABLE 11 AROUND HERE $>>$

\section{Conclusion}

This research has highlighted the significance of the NC500 as a key development contributing to the increase in tourism at a range of businesses within the Northern Highlands of Scotland. 
The route has been an important factor in helping to raise the profile of a number of businesses and there is evidence of growth across a variety of areas. The strategic aim of the NC500 was to give greater prominence to the location and landscape to help in the revival of the North Highland economy. The route was envisaged as a core economic development activity aiming to catalyse employment, build the rural economy and grow related tourism infrastructure (NC500, 2018). Previous research undertaken by University of Glasgow (Highlands and Islands Enterprise, 2017) attempted to establish the impact of NC500 in 2016. The fundamental problem of that study was it used 2015 as the baseline and examined 2016 impacts against 2015. The NC500 was launched in April 2015 so the baseline used in that study was flawed. The impact of NC500 has to be examined against a year prior to launch to provide a more accurate baseline. The findings presented in this study provides analysis since 2014 and offers a more accurate baseline.

The nature of the NC500 counters some of the research and accepted wisdom in relation to what makes a route successful. It is valuable to consider the features of the NC500 that differentiates it from others. Central to the popularity of the route was the early adoption of App based orientation, interpretation and marketing. This constitutes a free downloadable resource with a listing of more than 2,000 businesses on the route. The App can directly enhance the route with channels linked to interests such as heritage and history, food, scenic viewpoints, accommodation as well as downloadable traditional and contemporary music and other elements such as Scottish fairy-tales and historical stories. This moves interpretation and orientation beyond the physical to the virtual (see Timothy \& Boyd, 2015). The other significant element of marketing is the brand. North Coast 500 challenges those who would content that 'most branded places have evolved organically and their brand identities formulated through time and via spontaneous growth' (Timothy \& Boyd, 2015: p 231). In this 
case the brand, design and utilisation on social and digital media was consciously curated and marketed on all visual materials.

Similarly, the NC500 lacked the advantage of prestige or international designation. In contrast it was created to provide association with the key 'pull' factors of Northern, Coastal and Distance (500). The NC500 also challenges some of the rationale in route development, appeal and characteristics (see Timothy \& Boyd, 2015). For example, the distance for the main tourism markets in Scotland (notably some 4.5 hours drive from the Central Belt and the cities of Edinburgh and Glasgow). Furthermore, the quality of the road network counters the logical development of routes (based on quality infrastructure) envisaged by Prideaux (2000) and Timothy (2011). Technology plays a central part in orientation and marketing rather than a function of car mechanical development, such as self-drive cars. Indeed, the adoption of ICT in the form of the App download has been critical to the growth of NC500 self-drive tourists 'because enhanced information flow facilitates greater independence' (Ali \& Carson, 2011: 124). In attempting to characterise and understand the reasons for touring routes success (as in the case of NC500), it is clear that it is both a nature-based (Laws \& Scott, 2003) with some heritage elements (Caton \& Santos, 2007). The NC500 constitutes a success according to Carson and Cartan's (2011) criteria as summarised in Table 12.

$<<$ INSERT TABLE 12 AROUND HERE $>>$

In traffic management the increased utilisation of B roads and lesser routes with passing places has inevitably created some tensions, yet the seasonal extension of tourism demand and the generation of more jobs and business growth in fragile communities has countered such traffic issues. Notably, traffic issues or roads were not issues for visitors using the NC500, a majority 
of whom welcomed the opportunity to traverse minor roads in this remote destination (Highlands and Islands Enterprise, 2017).

Tourist destinations increasingly utilise various branding techniques to try and develop a unique position within an increasingly competitive environment (see Kozak \& Baloglu, 2011). There are a variety of challenges associated with developing any tourism product. There has recently been some negative media attention focusing on the effects of tourism and the increase in the number of people using the NC500 route. There has also been some concern expressed about the ways in which some users of the NC500 may be driving too fast.

This study has contributed to the literature on contemporary Scotland through focusing on a part of the country that has received relatively little attention from tourism researchers to date. The results of the research show that there has been an increase in a number of tourism-related business areas in the region that the NC500 is located within. As with previous research on route tourism, it highlights that tourists are able to opt-in and out of different offerings along the route and that such developments may bring different businesses closer together (see Hardy, 2003; Sykes \& Kelly, 2016; Timothy \& Boyd, 2015). Future research should include interviews with a variety of stakeholders to better understand their experiences of the NC500 development. Such data will help us further explore the social and cultural impacts of the development on a variety of different groups. 


\section{References}

Ali, A. \& Carson, D. (2011). 'Information communications technology (ICT) and the challenge of sustainable self-drive tourism'. In Prideaux, B. \& Carson, D. (Eds.) Drive Tourism: Trends and Emerging Markets. London: Routledge.

Basu, P. (2007). Highland Homecomings: Genealogy and Heritage Tourism in the Scottish Diaspora. London: Routledge.

BBC (2018a). 'Why are tourists flocking to Scotland?' Available at: https://www.bbc.co.uk/news/uk-scotland-43418122

BBC (2018b). 'Highlands and Islands on Lonely Planet's "Best in travel” list'. Available at: https://www.bbc.co.uk/news/uk-scotland-highlands-islands-45940644

Carson, D. \& Cartan, G (2011). 'Touring routes - types, successes and failures an international review'. In Prideaux, B. \& Carson, D. (Eds.) Drive Tourism: Trends and Emerging Markets. London: Routledge, 296-310.

Caton, K. \& Santos, C. (2007). 'Heritage tourism on route 66: Deconstructing nostalgia'. Journal of Travel Research, 45(4), 371-386.

Devine, T. (2000). The Scottish Nation 1700-2000. London: Penguin.

Dolesh, R. (2004). 'Tough terrain: the conflict associated with multi-use trials'. Parks and Recreation, 39(10), 56-63

Greiner, R., Mayocchi, C., Larson, S., Stoeckl, N. \& Schweiger, R. (2004). Benefits and costs of tourism for remote communities: case study for the Carpentaria Shire in North West Queensland. Darwin: CSIRO Sustainable Ecosystems and Tropical Savannas.

Hardy, A. (2003). 'An investigation into the key factors necessary for the development of iconic touring routes'. Journal of Vacation Marketing, 9(4), 314-330. 
Highlands and Islands Enterprise (2017). North Coast 500: Economic Baseline Study. Glasgow: University of Glasgow/Highlands and Islands Enterprise.

Kent, R. (1993). 'Attributes, features and reasons for enjoyment of scenic routes: A comparison of experts, residents and citizens'. Landscape Research, 18(2), 92-102.

Kozak, M. \& Baloglu, S. (2011). Managing and Marketing Tourist Destinations. London: Routledge.

Laws, E. \& Scott, N. (2003). 'Developing new tourism services: Dinosaurs, a new drive tourism resource for remote regions?'. Journal of Vacation Marketing, 9(4), 368-380.

Martin, A. \& McBoyle, G. (2006). 'Scotland's malt whisky trail: Management issues in a public-private tourism marketing partnership'. International Journal of Wine Marketing, 18(2), 98-111.

McCrone, D., Morris, A., \& Kieley, R. (1995). Scotland - the Brand: The Making of Scottish Heritage. Edinburgh: Edinburgh University Press.

Miller, D. (2001) (Ed.) Car Cultures. Oxford: Berg.

Mitchell, R., Charters, S., \& Albrecht, J. (2012). 'Cultural systems and the wine tourism product'. Annals of Tourism Research, 39(1), 311-335.

Moffat Centre (2018). Visitor Attraction Monitor 2018. Glasgow: Glasgow Caledonian University.

Moffat Centre (2019). Scottish Occupancy and Accommodation Survey 2018. Glasgow: Glasgow Caledonian University.

Nash, R. \& Martin, A. (2003). 'Tourism in peripheral areas - the challenges for northeast Scotland'. International Journal of Tourism Research, 5(3), 161-181.

North Coast 500 (2018). 'The ultimate road trip'. Available at https://www.northcoast500.com/ 
Pike, S. (2005). 'Tourism destination branding complexity'. Journal of Product \& Brand Management, 14(4), 258-259.

Office for National Statistics (2019) Overseas Travel and Tourism Quarterly. Available at: https://www.ons.gov.uk/peoplepopulationandcommunity/leisureandtourism/datasets/overseas travelandtourism

Prideaux, B. (2000). 'The role of transport in destination development'. Tourism Management, 21(1), 53-64

Prideaux, B. \& Carson, D. (2011) (Eds.) Drive Tourism: Trends and Emerging Markets. London: Routledge.

Pritchard, A. \& Morgan, N. (1996). 'Selling the Celtic Arc to the USA: A comparative analysis of the destination brochure images used in the marketing of Ireland, Scotland and Wales'. Journal of Vacation Marketing, 2(4), 346-365.

Rolfe, J. \& Flint, N. (2018). 'Assessing the economic benefits of a tourist access road: A case study in regional coastal Australia'. Economic Analysis and Policy, 58, 167-178.

Scotch Whisky Association (2019). Scotch whisky economic impact report 2018. Available at: https://www.scotch-whisky.org.uk/newsroom/scotch-whisky-economic-impact-report-2018/ Scottish Enterprise (2012) Output Measurement Framework Guidelines. Glasgow: Scottish Enterprise.

Scottish Government (2019). Multipliers. Available at: https://www2.gov.scot/Topics/Statistics/Browse/Economy/Input-Output/Mulitipliers

Stoffelen, A. \& Vanneste, D. (2016). 'Institutional (dis)integration and regional development implications of whisky tourism in Speyside, Scotland'. Scandinavian Journal of Hospitality and Tourism, 16(1), 42-60. 
Sykes, D. \& Kelly, K. (2016). 'Motorcycle drive tourism leading to rural tourism opportunities'. Tourism Economics, 22(3), 543-557.

Thanh, T. \& Kirova, V. (2018). 'Wine tourism experience: A netnography study'. Journal of Business Research, 83, 30-37.

Timothy, D. (2011). 'Highways and byways: car-based tourism in the US'. In Prideaux, B. \& Carson, D. (Eds.) Drive Tourism: Trends and Emerging Markets. London: Routledge, 172193.

Timothy, D. \& Boyd, S. (2015) Tourism and Trails: Cultural, Ecological and Management Issues. Bristol: Channel View Publications.

UK Government Department of Transport Road Traffic Statistics (2019) $\underline{\text { http://roadtraffic.dft.gov/uklocalauthorities/35 and http://roadtraffic.dft.gov.uk/downloads }}$

United Nations World Tourism Organisation (2019) https://www.eunwto.org/toc/unwtotfb/current

VisitBritain (2019a). Inbound town data. Available at: https://www.visitbritain.org/town-data VisitBritain (2019b). The GB Tourist 2018 Annual Report. Available at: https://www.visitbritain.org/sites/default/files/vb-corporate/40413193-

260c_gb_tourist_annual_report_2018_fv-v3.pdf

VisitScotland (2019). Key facts on Tourism in Scotland - 2018. Available at https:/www.visitscotland.org/binaries/content/assets/dot-org/pdf/research-papers-2/key-factson-tourism-in-scotland-2018-v2.pdf 
Tables

\begin{tabular}{|l|c|c|}
\hline Response & Number & $\mathbf{\%}$ \\
\hline $\begin{array}{l}\text { Willing to participate with NC500 Evaluation } \\
\text { Survey }\end{array}$ & 100 & 49 \\
\hline $\begin{array}{l}\text { Unwilling to participate with NC500 Evaluation } \\
\text { Survey }\end{array}$ & 33 & 16 \\
\hline Data Unavailable & 2 & 1 \\
\hline Recently Opened / Purchased No Data Available & 29 & 14 \\
\hline Awaiting Call Back (following 5 contacts) & 6 & 3 \\
\hline No Response & 33 & 16 \\
\hline Total Accommodation Stock Contacted & $\mathbf{2 0 3}$ & $\mathbf{1 0 0}$ \\
\hline
\end{tabular}

Table 1 Response analysis NC500 Evaluation Survey 


\begin{tabular}{|l|c|c|}
\hline Response & Number & $\mathbf{\%}$ \\
\hline $\begin{array}{l}\text { Data derived from Visitor Attraction Monitor 2014- } \\
\text { 2018 (Data in public domain) }\end{array}$ & 21 & 41.2 \\
\hline $\begin{array}{l}\text { Data derived from Visitor Attraction Monitor 2014- } \\
\text { 2018 (Data confidential) }\end{array}$ & 7 & 13.2 \\
\hline Contributed to NC 500 survey & 9 & 17.7 \\
\hline Unwilling to participate / data unavailable & 9 & 17.7 \\
\hline No Response & 5 & 9.8 \\
\hline Total Visitor Attraction Stock & $\mathbf{5 1}$ & $\mathbf{1 0 0}$ \\
\hline
\end{tabular}

Table 2 Data sources utilised in analysis of the Visitor Attraction located at or near the NC 500 route 


\begin{tabular}{|l|c|c|}
\hline Response & Number & \% \\
\hline $\begin{array}{l}\text { Willing to participate with NC500 Evaluation } \\
\text { Survey }\end{array}$ & 20 & 15.8 \\
\hline $\begin{array}{l}\text { Unwilling to participate with NC500 Evaluation } \\
\text { Survey }\end{array}$ & 41 & 32.5 \\
\hline Data Unavailable & 39 & 31.0 \\
\hline No Response & 26 & 20.6 \\
\hline Total Additional Tourism Businesses contacted & $\mathbf{1 2 6}$ & $\mathbf{1 0 0}$ \\
\hline
\end{tabular}

Table 3 Sources of data utilised in analysis of other tourism businesses impacted by the NC500 


\begin{tabular}{|l|c|c|c|c|c|}
\hline & $\mathbf{2 0 1 4}$ & $\mathbf{2 0 1 5}$ & $\mathbf{2 0 1 6}$ & $\mathbf{2 0 1 7}$ & $\mathbf{2 0 1 8}$ \\
\hline Average Room Occupancy & $52 \%$ & $61 \%$ & $68 \%$ & $73 \%$ & $78 \%$ \\
\hline Average Rates Achieved & $£ 46$ & $£ 54$ & $£ 66$ & $£ 74$ & $£ 82$ \\
\hline
\end{tabular}

Table 4: NC 500 Accommodation Businesses: Performance in Average Room Occupancy and Average Room Rate 2014-2018 ( $\mathrm{n}=100)$ 


\begin{tabular}{|l|c|c|c|c|c|}
\hline $\begin{array}{l}\text { Accommodation Indicative Quality Rating } \\
\text { (Multiple sources) }\end{array}$ & $\mathbf{2 0 1 4}$ & $\mathbf{2 0 1 5}$ & $\mathbf{2 0 1 6}$ & $\mathbf{2 0 1 7}$ & $\mathbf{2 0 1 8}$ \\
\hline 5 Star Luxury & $8 \%$ & $15 \%$ & $18 \%$ & $20 \%$ & $21 \%$ \\
\hline 4 Star & $13 \%$ & $16 \%$ & $19 \%$ & $22 \%$ & $23 \%$ \\
\hline 3 Star & $23 \%$ & $22 \%$ & $20 \%$ & $18 \%$ & $18 \%$ \\
\hline 2 Star & $30 \%$ & $25 \%$ & $23 \%$ & $23 \%$ & $21 \%$ \\
\hline Unclassified / Other & $26 \%$ & $22 \%$ & $20 \%$ & $17 \%$ & $17 \%$ \\
\hline
\end{tabular}

Table 5: NC500 Accommodation Businesses: Rating in Quality Assurance, based on VisitScotland Quality Assurance and Grading), Trip Advisor and other digital channels $(n=100)$. 


\begin{tabular}{|c|c|c|c|c|c|c|c|c|}
\hline Admission & Sample & $\begin{array}{c}\text { Visits } \\
\mathbf{2 0 1 4}\end{array}$ & $\begin{array}{c}\text { Visits } \\
\mathbf{2 0 1 5}\end{array}$ & $\begin{array}{c}\text { Visits } \\
\mathbf{2 0 1 6}\end{array}$ & $\begin{array}{c}\text { Visits } \\
\mathbf{2 0 1 7}\end{array}$ & $\begin{array}{c}\text { Visits } \\
\mathbf{2 0 1 8}\end{array}$ & $\begin{array}{c}\mathbf{\%} \\
\mathbf{1 8} / \mathbf{1 4}\end{array}$ & $\begin{array}{c}\text { Diff } \\
\mathbf{( 1 8 - 1 4})\end{array}$ \\
\hline Free & 11 & 403,514 & 416,469 & 476,859 & 499,288 & 483,775 & 19.9 & 80,261 \\
\hline Paid & 16 & 307,263 & 309,711 & 380,376 & 527,495 & 435,531 & 41.7 & 128,268 \\
\hline Total & 27 & 710,777 & 726,180 & 857,235 & $1,026,783$ & 919,306 & 29.3 & 208,529 \\
\hline
\end{tabular}

Table 6: NC500 Aggregate Visitor Attraction Businesses: Performance in Visits 2014-2018 $(\mathrm{n}=27)$ 


\begin{tabular}{|c|c|c|c|c|c|c|c|c|}
\hline Attraction Name & $\begin{array}{l}\text { Visits } \\
2014\end{array}$ & $\begin{array}{l}\text { Visits } \\
2015\end{array}$ & $\begin{array}{l}\text { Visits } \\
2016\end{array}$ & $\begin{array}{l}\text { Visits } \\
2017\end{array}$ & $\begin{array}{l}\text { Visits } \\
2018\end{array}$ & $\begin{array}{c}\% \\
18 / 14\end{array}$ & $\begin{array}{l}\text { Diff (18- } \\
\text { 14) }\end{array}$ & Free \\
\hline Dunrobin Castle & 67,209 & 72,804 & 84,930 & 103,200 & 112,475 & $67 \%$ & 45,299 & \\
\hline Tain Through Time & 6,097 & 5,924 & 4,929 & 8,567 & 9,525 & $56 \%$ & 3,428 & \\
\hline $\begin{array}{l}\text { Ullapool Museum and } \\
\text { Visitor Centre }\end{array}$ & 6,676 & 5,403 & 5,565 & 5,041 & 6,007 & $-10 \%$ & -669 & \\
\hline $\begin{array}{l}\text { Gairloch Heritage } \\
\text { Museum }\end{array}$ & 6,124 & 6,026 & 6,379 & 6,903 & 6,616 & $8 \%$ & 492 & \\
\hline $\begin{array}{l}\text { Inverness Museum } \\
\text { and Art Gallery }\end{array}$ & 42,369 & 49,411 & 48,726 & 53,545 & 48,542 & $14 \%$ & 6,173 & $\mathbf{F}$ \\
\hline $\begin{array}{l}\text { Laidhay Croft } \\
\text { Museum }\end{array}$ & 1,498 & 1,528 & 1,720 & 2,069 & 1,592 & $6 \%$ & 94 & \\
\hline Strathnaver Museum & 3,996 & 4,109 & 5,028 & 5,550 & 5,190 & $30 \%$ & 1,194 & \\
\hline $\begin{array}{l}\text { Caithness Broch } \\
\text { Centre }\end{array}$ & 706 & 508 & 631 & 667 & 432 & $-39 \%$ & -274 & $\mathbf{F}$ \\
\hline $\begin{array}{l}\text { Knockan Crag Visitor } \\
\text { Centre }\end{array}$ & 11,763 & 7,739 & 7,044 & 3,470 & 14,592 & $24 \%$ & 2,829 & $\mathbf{F}$ \\
\hline $\begin{array}{l}\text { Groam House } \\
\text { Museum }\end{array}$ & 5,533 & 5,151 & 5,476 & 5,934 & 5,593 & $1 \%$ & 60 & $\mathbf{F}$ \\
\hline $\begin{array}{l}\text { Glenmorangie } \\
\text { Distillery }\end{array}$ & 21,862 & 22,852 & 27,948 & 26,336 & 26,336 & $21 \%$ & 4,474 & \\
\hline Attadale Gardens & 5,639 & 5,318 & 6,689 & 6,493 & 7,148 & $27 \%$ & 1,509 & \\
\hline $\begin{array}{l}\text { Timespan Heritage } \\
\text { Centre }\end{array}$ & 11,965 & 13,796 & 16,092 & 14,441 & 14,407 & $20 \%$ & 2,442 & \\
\hline Inverewe Garden & 62,734 & 56,451 & 91,576 & 191,951 & 80,913 & $29 \%$ & 18,179 & \\
\hline Fort George & 55,240 & 57,158 & 60,924 & 74,558 & 71,906 & $30 \%$ & 16,666 & \\
\hline $\begin{array}{l}\text { Torridon Countryside } \\
\text { Centre }\end{array}$ & 53,496 & 36,106 & 50,281 & 49,127 & 51,539 & $-4 \%$ & $\begin{array}{c}- \\
1,957\end{array}$ & $\mathbf{F}$ \\
\hline $\begin{array}{l}\text { Lybster Harbour } \\
\text { Visitor Centre }\end{array}$ & 6,963 & 6,640 & 7,542 & 6,576 & 7,048 & $1 \%$ & 85 & $\mathbf{F}$ \\
\hline $\begin{array}{l}\text { The Castle \& } \\
\text { Gardens of Mey }\end{array}$ & 20,432 & 18,706 & 21,622 & 25,454 & 28,961 & $42 \%$ & 8,529 & \\
\hline Rogie Falls & 53,606 & 57,949 & 67,929 & 75,044 & 73,584 & $37 \%$ & 19,978 & $\mathbf{F}$ \\
\hline Balblair Forest & 11,160 & 11,000 & 11,000 & 13,797 & 13,140 & $18 \%$ & 1,980 & $\mathbf{F}$ \\
\hline Corrieshalloch Gorge & 63,279 & 76,065 & 113,730 & 140,328 & 110,573 & $75 \%$ & 47,294 & $\mathbf{F}$ \\
\hline
\end{tabular}

Table 7: NC500 Individual Visitor Attraction Businesses: Performance in Visits 2014-2018 


\begin{tabular}{|l|c|c|c|c|}
\hline Impact Indicators & $\mathbf{2 0 1 5}$ & $\mathbf{2 0 1 6}$ & $\mathbf{2 0 1 7}$ & $\mathbf{2 0 1 8}$ \\
\hline Increase in sales performance & $+14 \%$ & $+19 \%$ & $+18 \%$ & $+12 \%$ \\
\hline Recognisable increase in tourist consumers & Yes & Yes & Yes & Yes \\
amongst sample & $(65 \%)$ & $(70 \%)$ & $(75 \%)$ & $(65 \%)$ \\
\hline
\end{tabular}

Table 8: NC500 Other tourism businesses: Performance Indicators 2014-2018 ( $\mathrm{n}=20)$ 


\begin{tabular}{|l|c|c|c|}
\hline $\begin{array}{l}\text { NC 500 Tourism } \\
\text { Business }\end{array}$ & $\begin{array}{c}\text { Estimated } \\
\text { Sales 2018 }\end{array}$ & $\begin{array}{c}\text { Estimated Sales } \\
\text { Generated by NC 500 } \\
\mathbf{( \% )}\end{array}$ & $\begin{array}{c}\text { Estimated Sales } \\
\text { Generated by NC 500 }\end{array}$ \\
\hline Accommodation & $29.7 \mathrm{~m}$ & $25.3 \%$ & $7.51 \mathrm{~m}$ \\
\hline Visitor Attractions & $6.8 \mathrm{~m}$ & $24.6 \%$ & $1.67 \mathrm{~m}$ \\
\hline $\begin{array}{l}\text { Other Tourism } \\
\text { Businesses }\end{array}$ & $11.6 \mathrm{~m}$ & $36.9 \%$ & $4.28 \mathrm{~m}$ \\
\hline Total & $\mathbf{4 8 . 1 m}$ & $\mathbf{2 7 . 9 \%}$ & $\mathbf{1 3 . 4 6 m}$ \\
\hline
\end{tabular}

Table 9: NC500 Estimated Sales by Sector 


\begin{tabular}{|l|c|c|c|c|c|c|c|}
\hline $\begin{array}{l}\text { NC500 Tourism } \\
\text { Business }\end{array}$ & $\begin{array}{c}\text { Estimated } \\
\text { Sales } \\
\mathbf{2 0 1 8}(\mathfrak{f m})\end{array}$ & $\begin{array}{c}\text { Purchases } \\
\text { at Basic } \\
\text { Prices } \\
\mathbf{( f m )}\end{array}$ & $\begin{array}{c}\text { Direct } \\
\text { GVA } \\
\mathbf{( f m )}\end{array}$ & $\begin{array}{c}\text { Indirect } \\
\text { Output } \\
(\mathfrak{f m})\end{array}$ & $\begin{array}{c}\text { Induced } \\
\text { Output } \\
(\mathfrak{f m})\end{array}$ & $\begin{array}{c}\text { Total } \\
\text { Output } \\
\text { GVA } \\
\mathbf{( f m )}\end{array}$ & $\begin{array}{c}\text { Additional } \\
\text { GVA } \\
\text { generated } \\
\text { by NC500 } \\
(\mathfrak{f m})\end{array}$ \\
\hline Accommodation & $29.7 \mathrm{~m}$ & 26.1 & 8.32 & 8.37 & 7.17 & 49.96 & \\
\hline $\begin{array}{l}\text { Visitor } \\
\text { Attractions }\end{array}$ & $6.8 \mathrm{~m}$ & 5.98 & 1.9 & 1.91 & 1.64 & 11.43 & \\
\hline $\begin{array}{l}\text { Other Tourism } \\
\text { Businesses }\end{array}$ & $11.6 \mathrm{~m}$ & 10.2 & 3.25 & 3.27 & 2.80 & 19.52 & \\
\hline Total & $\mathbf{4 8 . 1 m}$ & $\mathbf{4 2 . 2 8}$ & $\mathbf{1 3 . 4 7}$ & $\mathbf{1 3 . 5 5}$ & $\mathbf{1 1 . 6 1}$ & $\mathbf{8 0 . 9 1}$ & $\mathbf{2 2 . 8 9}$ \\
\hline
\end{tabular}

Table 10: Estimated GVA derived from NC500 Visitation 2018 


\begin{tabular}{|l|c|c|c|c|c|}
\hline NC500 Tourism & $\begin{array}{c}\text { Estimated } \\
\text { Direct } \\
\text { FTE }\end{array}$ & $\begin{array}{c}\text { Indirect } \\
\text { FTE }\end{array}$ & $\begin{array}{c}\text { Induced } \\
\text { FTE }\end{array}$ & $\begin{array}{c}\text { Total } \\
\text { Employment }\end{array}$ & $\begin{array}{c}\text { Estimated Total } \\
\text { Employment } \\
\text { generated by } \\
\text { NC500 }\end{array}$ \\
\hline Accommodation & 192 & 46.8 & 22.6 & 261.4 & \\
\hline Visitor Attractions & 174 & 42.4 & 20.5 & 236.9 & \\
\hline $\begin{array}{l}\text { Other Tourism } \\
\text { Businesses }\end{array}$ & 98 & 23.9 & 11.5 & 133.4 & \\
\hline Total FTE & $\mathbf{4 6 4}$ & $\mathbf{1 1 3 . 1}$ & $\mathbf{5 4 . 6}$ & $\mathbf{6 3 1 . 7}$ & $\mathbf{1 7 8 . 7}$ \\
\hline
\end{tabular}

Table 11 Estimated FTE Employment derived from NC500 Visitation 2018 


\begin{tabular}{|l|l|}
\hline Success factors of Tourism Routes & Evidence in context \\
& of N500 \\
\hline Number of vehicles using a particular segment of the route & Yes \\
\hline Tourist Expenditure & Yes \\
\hline Length of Stay & Yes \\
\hline Tourist Satisfaction & Yes \\
\hline Number of Stops & Yes \\
\hline Traffic management & Yes / Partial \\
\hline Industry Collaboration & Yes \\
\hline Community Values & Yes / Partial \\
\hline
\end{tabular}

Table 12: Success factors of tourist route development and the performance of the NC500 (after Carson \& Carton, 2011) 


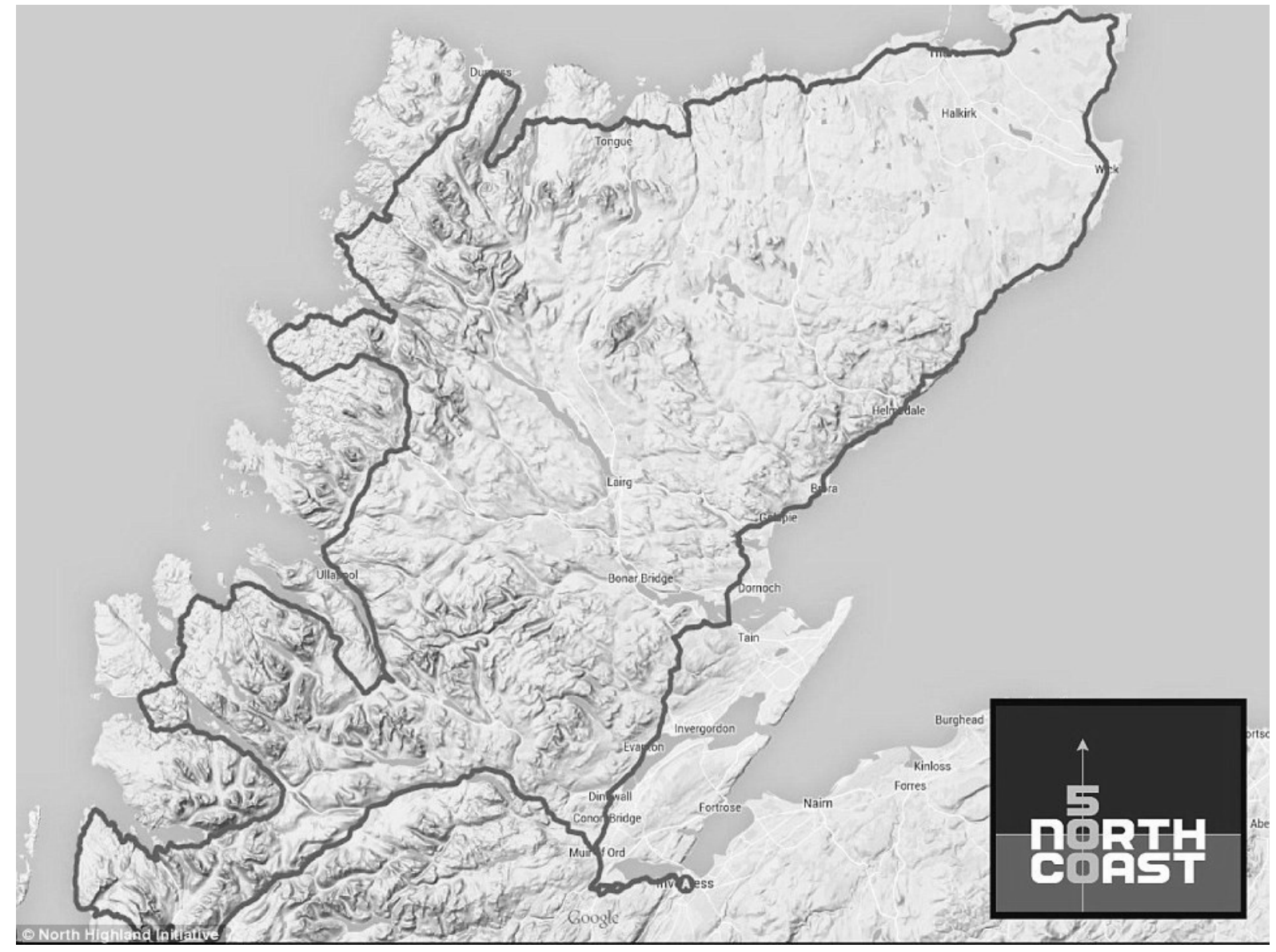

Figure 1: North Coast 500 route 
The North Coast 500

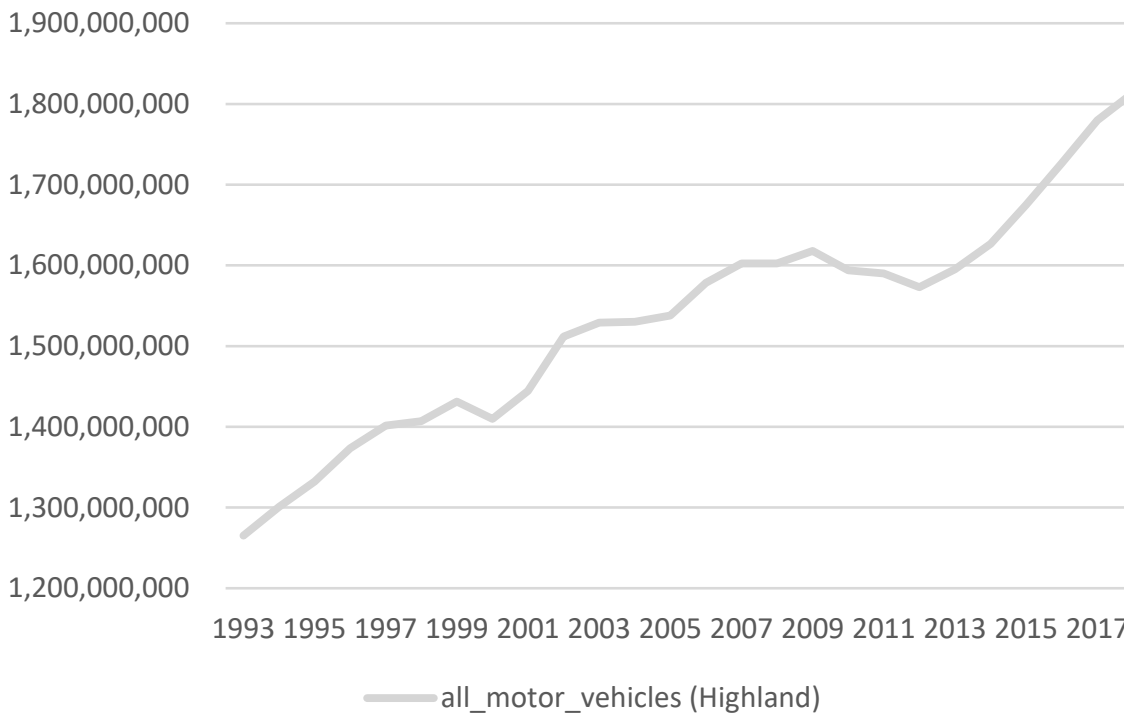

all_motor_vehicles (Highland)

Figure 2: All Highland Motor vehicle transport 1993-2017 (Transport Scotland, 2019) 
The North Coast 500

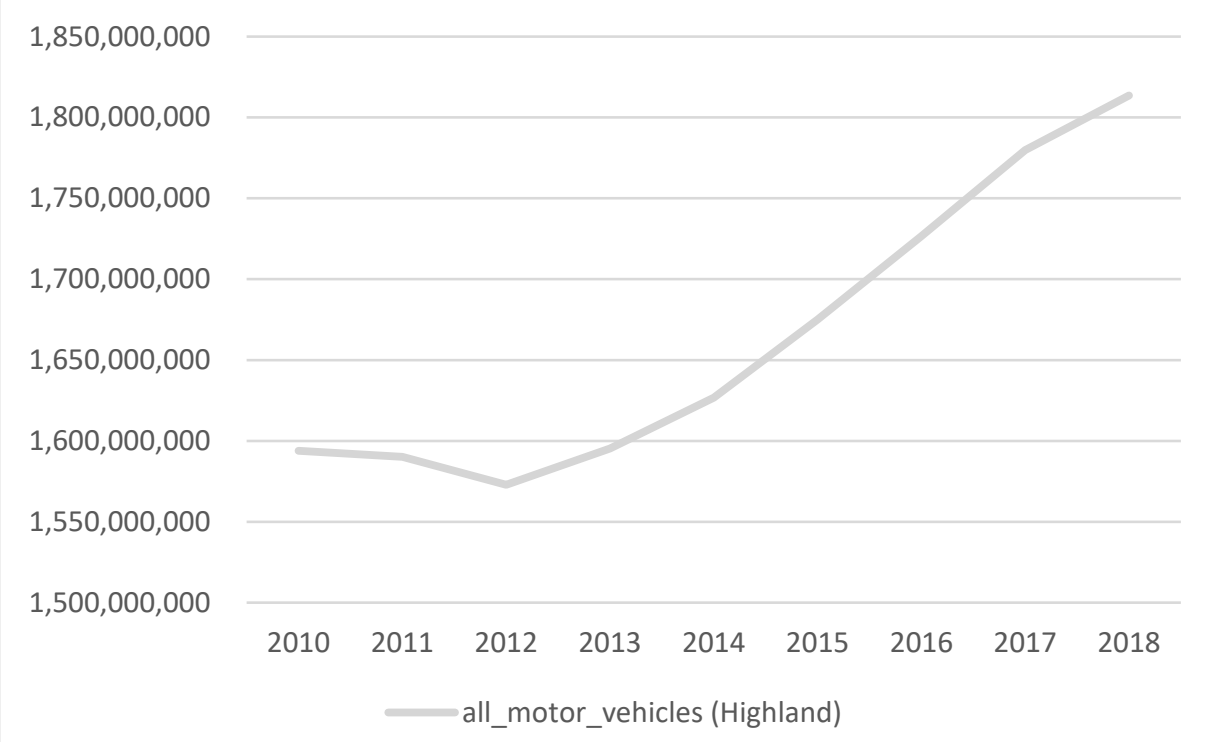

Figure 3: All Highland Motor vehicle transport 2010-2018 (Transport Scotland 2019) 


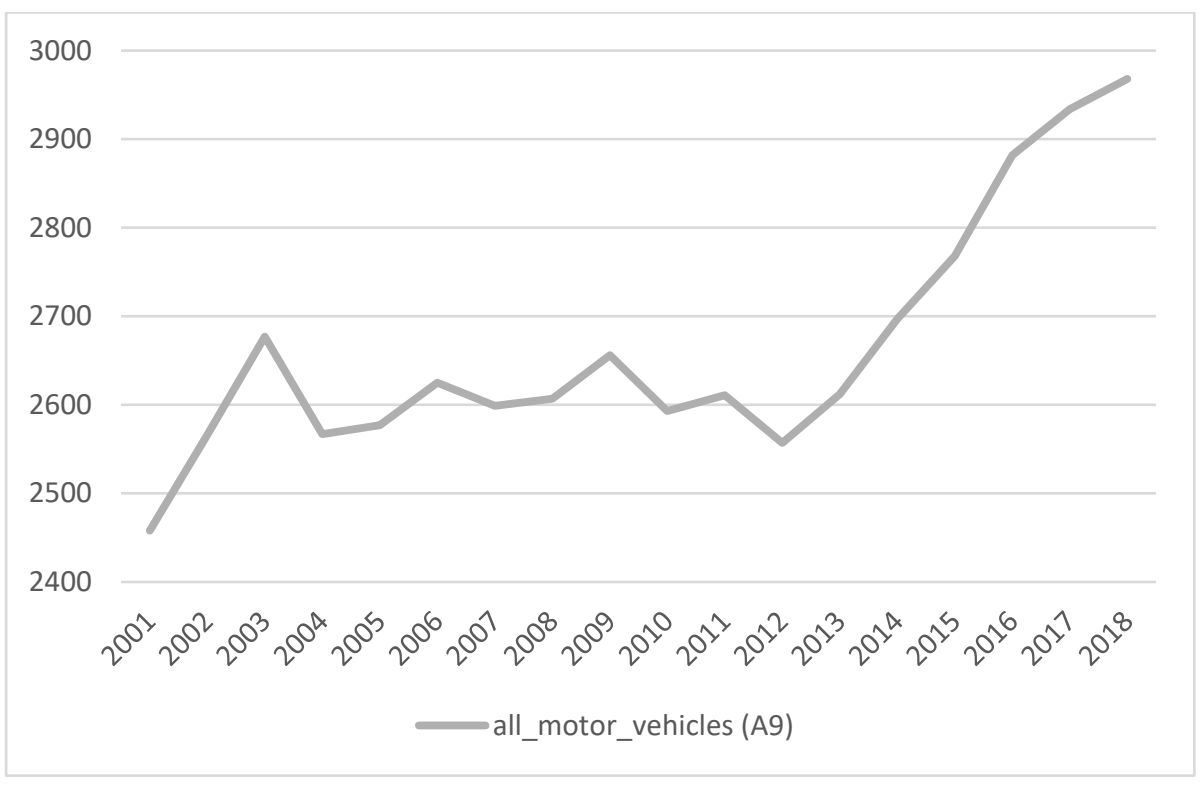

Figure 4: Total Motor Vehicles on A9 2001-2018 (Transport Scotland, 2019) 
The North Coast 500

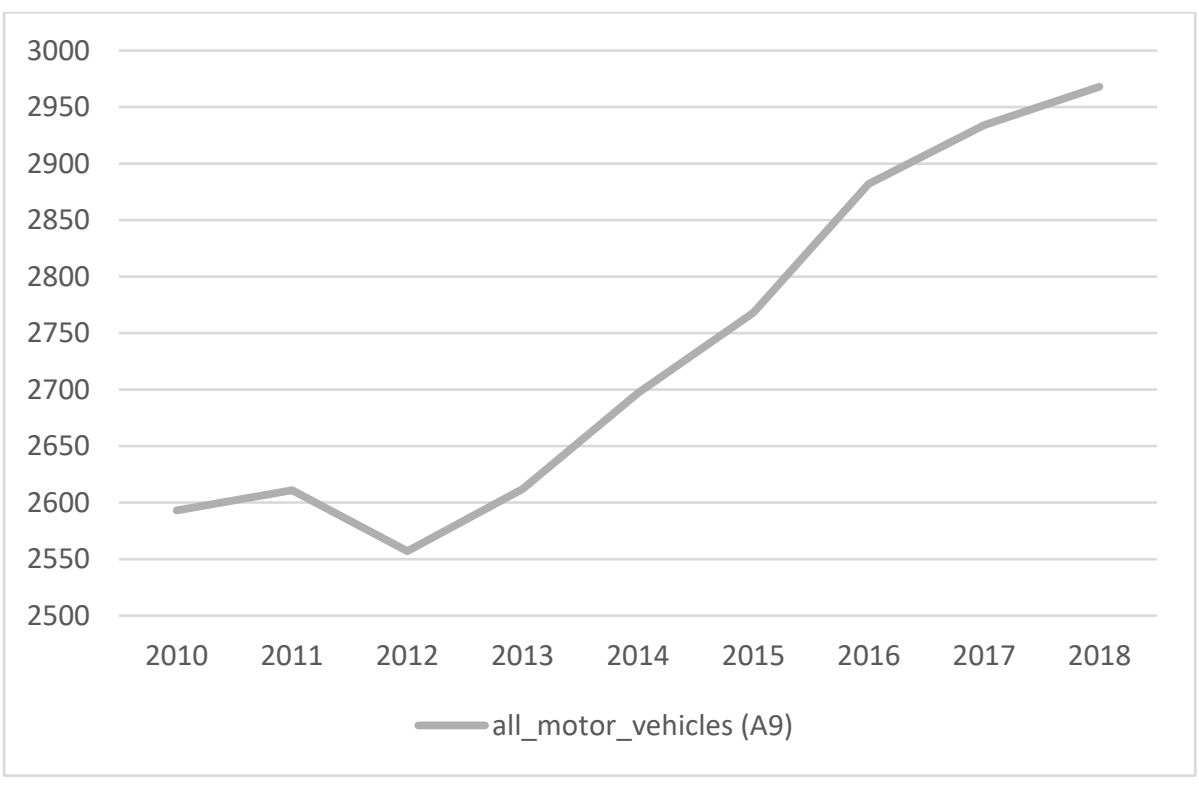

Figure 5: Total Motor Vehicles on A9 2010-2018 (Transport Scotland, 2019) 
The North Coast 500

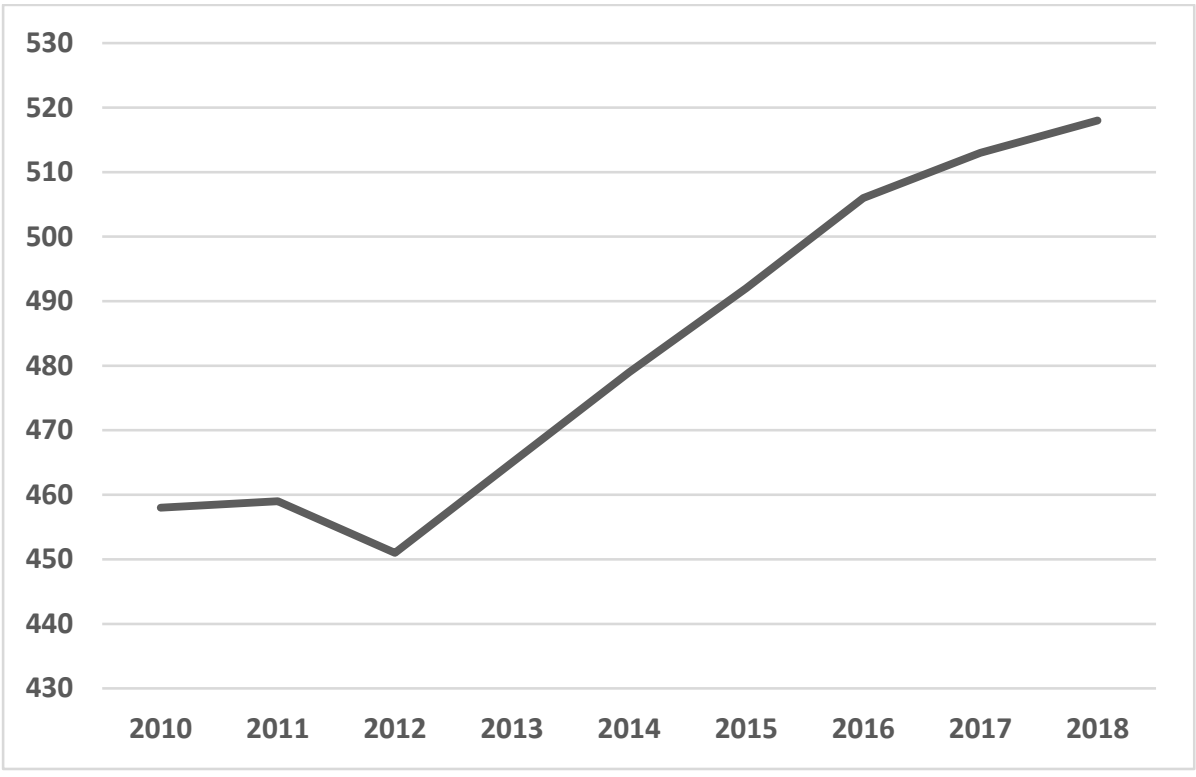

Figure 6: Total Motor Vehicles on A836 2010-2018 (Transport Scotland, 2019) 
The North Coast 500

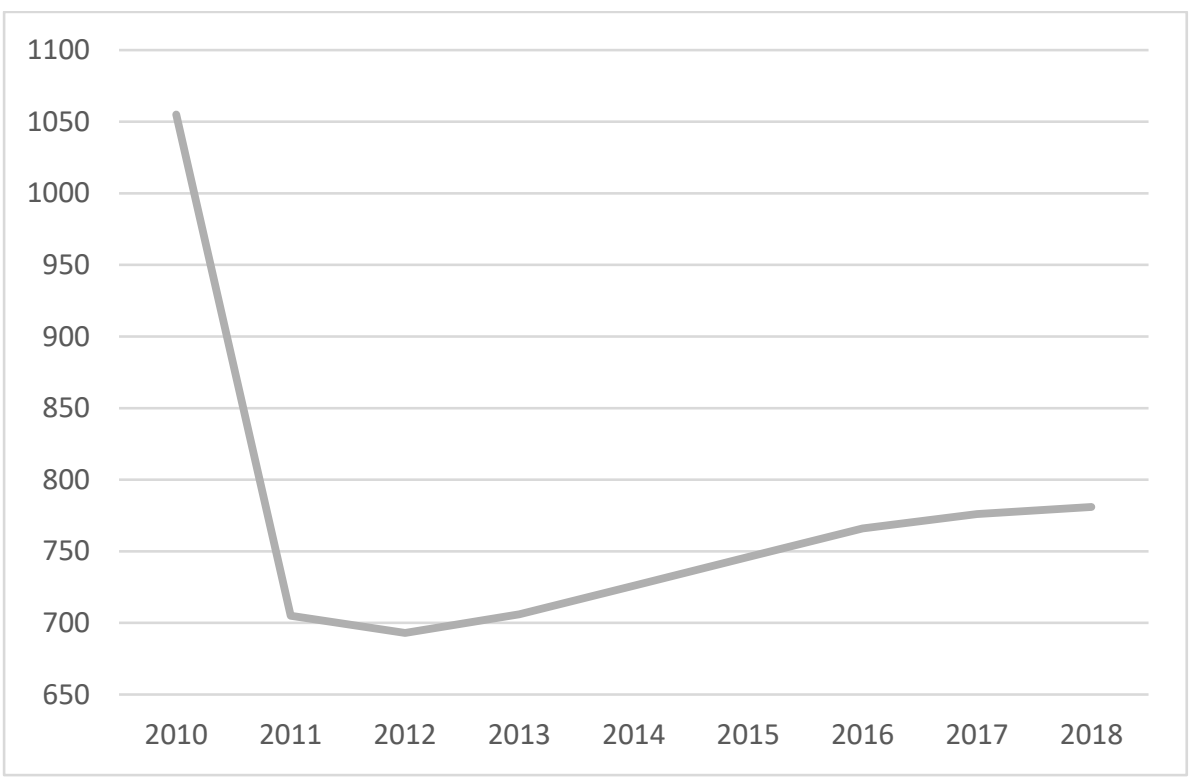

Figure 7: Total Motor Vehicles on A837 2010-2018 (Transport Scotland, 2019) 


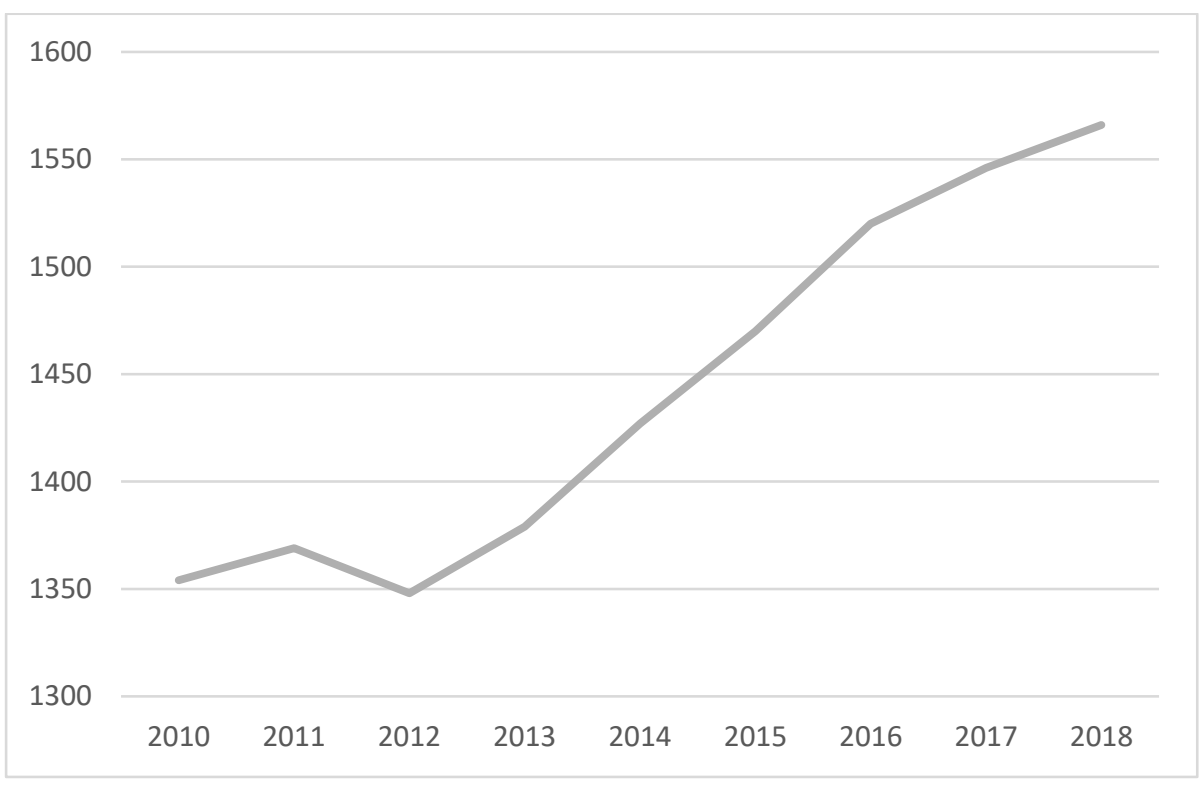

Figure 8: Total Motor Vehicles on A832 2010-2018 (Transport Scotland, 2019) 